돼지의 Leptin receptor 유전자내 초위성체 다형성에

따른 개체별 성장곡선 특성

조용민 · 최봉환 · 김태헌 · 이지웅 · 정일정

농촌진흥청 축산기술연구소

\title{
Characteristics of Individual Growth Curve by Porcine LEPR-derived Microsatellite Polymorphisms
}

\author{
Y. M. Cho, B. H. Choi, T. H. Kim, J. W. Lee, and I. C. Cheong
}

National Livestock Research Institute, RDA.

\begin{abstract}
This study was conducted to estimate the growth curve parameters of 253 heads of F2 population produced by inter-crossing F1 from Korean Native boars and Landrace sows, and to estimate the effects of Leptin receptor gene $(L E P R)$ on their growth characteristics. Growth curve parameters were estimated from nonlinear regression using Gompertz model individually.

Average mature weight and average maturing rate estimated were $179.69 \pm 4.40 \mathrm{~kg}$ and $0.3103 \pm 0.0043$, respectively. The effect of sex was insignificant for all the parameters estimated from Gempertz model(p $>.05)$, and the effect of calving group was significant for mature weight and maximum growth rate at inflection point (I <.05). The effect of $L E P R$ genotype were significant for all the growth curve parameters(I <.05). According from the results of the least squares means of growth curve parameters by $L E P R$ genotypes, mature weight and point of inflection were highest in genotype AA in which the maturing rate was the lowest, and were lowest in genotype DD in which maturing rate was the highest, reversely.
\end{abstract}

(Key words : Leptin receptor, Growth Curve Parameter, Gompertz Model)

$$
\text { I 서 론 }
$$

Leptin 호르몬은 비만 유전자(obese gene)에서 기인되고 주로 지방세포로부터 생성되어 뇌의 시상하부와 뇌하수체 전엽에 작용하여 식욕과 에너지 균형을 조절하는 중요한 역할을 담당하 고 있으며(Barb 등, 1998; Roh 등, 2001; Baratta 등, 2002), 생체의 에너지대사에 관여하는 것으 로 알려져 있다(Zhang 등, 1994). Leptin이 결핍 되면 식욕증가와 체중증가를 가져오고, 결과적 으로 축적된 지방세포에서 합성되는 Leptin 농도가 높아져 뇌에게 음식물 섭취를 줄이도 록 신호를 보내게 된다. 비만에 걸린 대부분
의 사람들은 혈중 Leptin 농도가 높게 나타나며 이것은 Leptin receptor $(L E P R)$ 가 Leptin과 반응을 하지 않아 비만이 나타나는 것으로 이해되고 있 으며, 또한 Leptin은 성장호르몬의 분비를 조절하 는 것으로 밝혀지고 있다(Lin 등, 2003).

$L E P R$ 은 Leptin 유전자의 조절과 밀접한 관계 가 있고 (Zhang 등, 1997), LEPR의 돌연변이가 인간과 설치류의 비만과 관련이 있다고 보고된 바 있다(Reichart 등, 2000; Clement 등, 1998; Chen 등, 1996). 돼지에 있어서 $L E P R$ 은 등지방 두께와 일당증체량에 연관 가능성이 있는 후보 유전자로 여겨지고 있다. Vincent 등(1997)은 돼 지 LEPR의 Hinf I 다형성에 연구하였고 6번 염

Corresponding author : Y. M. Cho, National Livestock Research Institute, Omockchun-dong Suwon 441-706, Korea. E-mail: variance@rda.go.kr 
색체의 유전자지도와 함께 염색체상의 위치를 규명하였다. 그러나 Ramsay 등(1998)에 의해 돼 지의 Leptin 유전자의 발현 수준과 생산형질과의 연관성은 보고된 바 있지만, $L E P R$ 이 경제형질에 미치는 효과에 대한 연구는 미비한 상태이다. 따 라서 돼지의 LEPR 유전자내 초위성체 다형성과 경제형질과의 관련성 조사를 통한 유전적 표지 인자를 발굴하게 된다면 효율적인 돼지의 능력 개량을 위한 MAS(marker assisted selection) 기법 적용에 필요한 소재로 이용할 수 있을 것이다.

본 연구에서 조사한 돼지의 경제형질은 개 체의 일령별 생체중으로서 가축의 성장 및 에 너지 대사에 관여하는 요인들이 가축의 전생애 에 걸쳐 지속적인 영향을 끼치거나, 혹은 일정 시점에서 발현되어 관여하거나 중단될 수도 있 다는 점을 고려하여 성장형질로서 일정 시점에 측정된 체중만을 이용하는 것보다는 성장 형태 의 전반에 걸친 정보를 이용하여 유전적 다형성 과의 관련성을 분석하는 것이 바람직할 것으로 판단하였다. 이러한 이산적인 체중 측정 시기간 에 대한 내삽(interpolation)이 가능한 비선형의 성장곡선 모형을 적용하여 성장률과 변곡점과 같은 성장 특성의 계산을 통해 성장에 관한 정 보를 축약 시켜내는 방법의 유용성은 Brown 등 (1976)에 의해 보고된 바 있다.

따라서 본 연구는 최근 국내 고유의 유전자 원으로 주목받고 있는 재래돼지와 랜드레이스 종간 교잡종의 성장 특성을 규명하고, Leptin receptor와 연관되어있는 초위성체 표지인자를 이용하여 유전적 다형성에 따른 성장특성의 비교를 통해 유용한 유전적 표지인자로서 $L E P R$ 유전자내 초위성체 다형성의 이용 가능 성을 밝히고자 실시하였다.

\section{ㅍ 재료 및 방법}

\section{1. 공시동물}

축산기술연구소의 순종 재래돼지 5 두와 랜드 레이스 9두로부터 생산한 F1 세대의 수컷 1두 와 암컷 2두 이상을 전형매 교배하여 얻은 $\mathrm{F} 2$, 354두를 본 실험에 이용하였다.

\section{2. 초위성체 표지인자}

유전자형 분석에 사용한 LEPR내에 존재하 는 초위성체 표지인자는 Genbank에 등록되어 있는 염기서열정보(Accession No. AF184172)를 근거로(CA)n의 dinucleotide 반복서열 형태를 가 지고 있었다. PCR을 위한 primer는 forward primer 5'-aatggaaactcttcccagct-3'와 reverse primer 5'-cattcgaactgttcattgccat-3'을 각각 합성하여 사용 하였다.

\section{3. $\mathrm{PCR}$ 에 의한 $\mathrm{DNA}$ 증폭}

PCR 반응액 조성은 PCR reaction buffer $(10 \mathrm{mM}$ Tris- $\mathrm{HCl}, \mathrm{pH} 8.3,50 \mathrm{mM} \mathrm{KCl}, 1.5 \mathrm{mM}$ $\mathrm{MgCl}_{2}$ )와 $2.5 \mathrm{mM} \mathrm{dNTPs}$, 3pmol fluorescent dye labeling primer pairs, 10ng의 template DNA, 0.5U Taq DNA polymerase(TaKaRa Shuzo Co., Shiga, Japan)와 $\mathrm{ddH}_{2} \mathrm{O}$ 를 사용하여 총 반응액은 $10 \mu l$ ! 하였다. PCR 반응에는 GeneAmp PCR System 9600(Perkin-Elmer Co., USA)를 사용하였고, PCR 조건은 $94^{\circ} \mathrm{C}$ 서 5 분간 pre-denaturation 한 후 $94^{\circ} \mathrm{C}$ 서 30 초 (denatruation), $60^{\circ} \mathrm{C}$ 서 40 초(annealing), $72^{\circ} \mathrm{C}$ 서 1분(extention)을 35cycles 수행한 후 마지막으 로 $72^{\circ} \mathrm{C}$ 서 10 분간 최종 extention과정을 수행 하였다. PCR증폭 산물은 증폭된 단편의 크기가 예상된 allele size 범위내에 존재하는지, PCR 조건의 적정성 여부를 확인하기 위하여 $\mathrm{EtBr}$ (ethidium bromide)이 포함된 2\% agarose gel에 전기영동하고 $\mathrm{UV}$ 상에서 관찰하였다.

\section{4. 유전자형 분석}

PCR 산물은 적정량의 deionized water로 희석 하고 DNA : formamide : size standard(Genescan350 TAMRA)를 $1 \mu \ell \quad \mu \ell \quad \mu \ell$ 비율로 혼 합하여 $95^{\circ} \mathrm{C}$ 이상에서 3 분간 denaturation시키 고, ABI 310 Genetic Analyzer(Perkin-Elmer Co., USA)로 분석하였다. GeneScan software version 2.1(Perkin-Elmer Co., USA)을 이용하여 PCR 산 물인 DNA 절편의 양과 크기에 대한 자료를 모 
아 수집하였다. 전기영동시 Performance Optimized Polymer 4(POP4) (PE Appiled Biosystems)와 $10 \times$ Buffer (with EDTA)를 $1 \times$ 로 희석하 여 사용하였고, run time은 22분으로 하였다. 유 전자형은 Genotyper software version 2.5(PerkinElmer Co., USA)를 이용하여 분석하였다. F2 세대 집단에서 얻어진 대립유전자는 $\mathrm{A}(255 \mathrm{bp})$, B(259bp), C(261bp), D(263bp), E(265bp), F(267bp) 의 6 가지 형태로 나타났으며, 가능한 유전자형 21 개 유형 가운데 본 실험집단에서는 19 가지의 유전자형 조합이 발현되었으며, 유전자형에 따 른 분포는 Fig. 1에 표시한 바와 같다. 이 가 운데 성장곡선 추정과정에서 수렴여부와 유전 자형별 개체 분포를 고려하여 9 개의 유전자형 에 대한 253 두의 자료를 분석에 이용하였다.

\section{5. 통계적 분석 방법}

비선형 회귀식에 의한 체중의 성장곡선 함수 의 추정은 SAS@8.1 Package/PC (SAS, 1990)의 비선형 회귀 분석 절차인 PROC NLIN을 이용하 였으며, 편도 함수의 지정이 필요하지 않은 탐색 기법인 다변량 정활 반복법(multivariate secant iterative method)으로서 DUD(Doesn't Use Derivative) 방법을 사용하였다. 체중의 성장곡선 모수를 개 체별로 추정하기 위해 이용한 Gompertz 모형 (Winsor, 1932)은 다음과 같다. 실제 분석에 이용 된 일령별 체중자료는 월령으로 변환시켜서 모수 추정을 위한 반복 계산 시간을 단축하였다.

$$
W_{t}=A e^{-b e^{-k t}}
$$

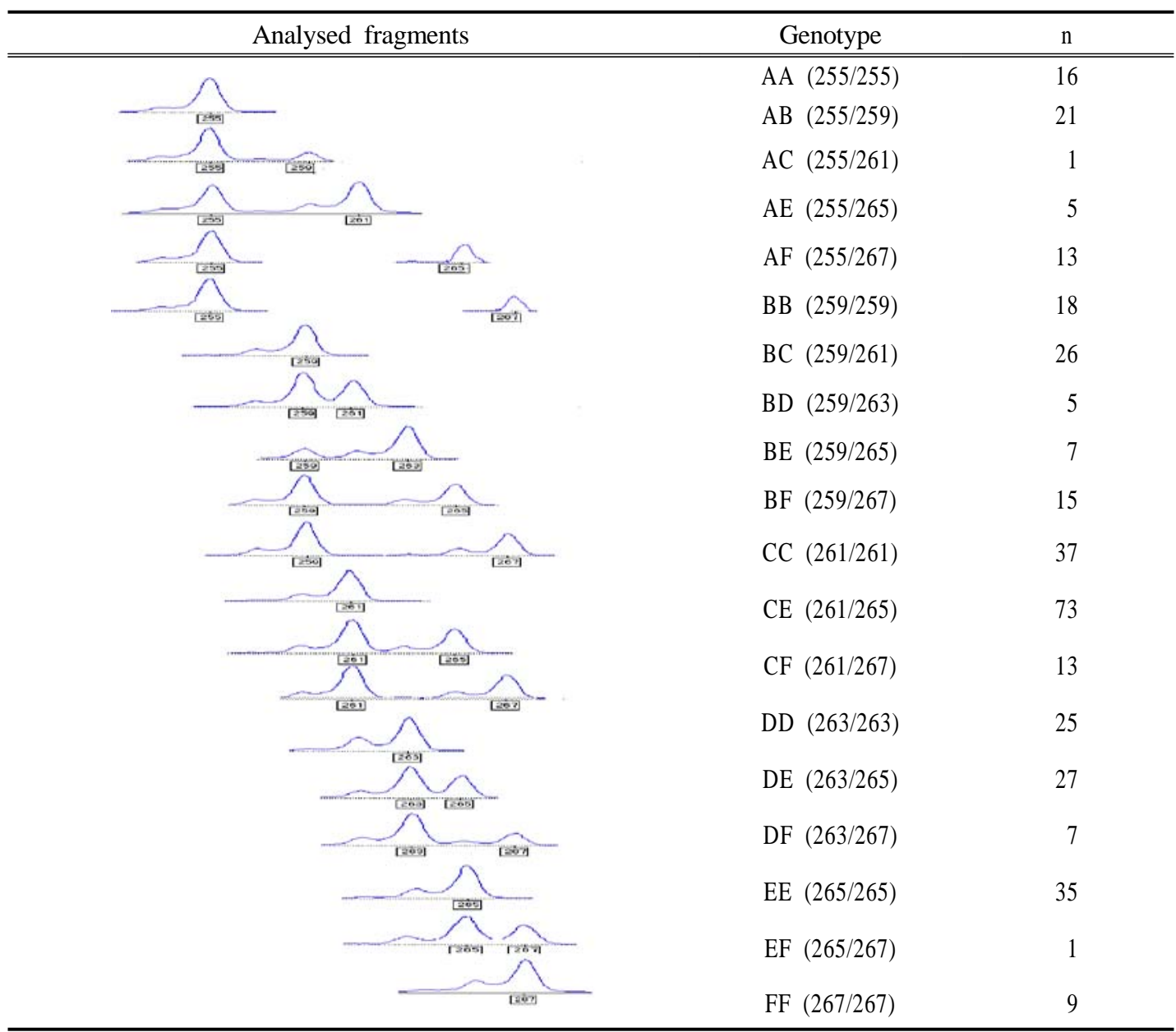

Fig. 1. Genotype of LEPR microsatellite marker for F2. 
위의 모형에서 $W_{t}$ 는 체중측정 월령인 $t$ 월령 에서 체중, $A$ 는 성장 곡선의 점근 상한계(upper asymptote) 혹은 성숙 체중(mature weight)을 의 미하며, $b$ 는 성장비율 모수(생시 체중에 대한 성숙 체중의 비율)이다. 그리고 $k$ 는 성숙률 (maturing rate)에 관한 모수이며 $e$ 는 지수 (exponential)이다.

개체별로 추정한 성장곡선 모수를 이용하여 성장특성에 관한 형질을 유도하였는데, 변곡점 $\left(t_{I}\right)$ 은 성장곡선의 기울기가 최대가 되는 월령 으로, 즉 성장곡선 추정에 이용한 Gompertz곡 선의 $t$ 에 대한 이차 미분함수가 0 이 되는 지점 으로 계산하였다. 실제 Gompertz 모형의 특성상 성숙체중 $(A)$ 에 대한 체중 추정치가 약 $36.8 \%$ 되는 지점이다. 그리고 변곡점에서의 체중 $\left(W_{t_{t}}\right)$ 과 변곡점에서의 증체 속도인 최대 증체율 $\left(\partial W_{t} / \partial t\right)$ 을 계산하였다. 이와 같이 추정한 개 체별 성장곡선 모수와 성장 특성에 대한 $L E P R$ 표지인자의 다형성 효과를 추정하고자 성별, 분만그룹 및 $L E P R$ 표지인자의 유전자형을 고 정효과로 포함한 일반선형 모형 분석을 실시하 고 평균간 최소 유의차 검정을 실시하였다.

\section{III 결과 및 고찰}

본 연구에서 이용한 재래돼지와 랜드레이스 종의 교잡에 의한 F2 세대의 개체별 성장곡선 모수와 성장 특성치의 일반 평균을 Table 1에 표시하였다. F2 세대에 대해 추정한 성장 특성 치의 분포는 충분한 변이를 보이는 바, $L E P R$ 표지인자의 유전적 다형성에 따른 성장 특성에 대한 효과 추정을 위한 집단으로서 적절한 것 으로 사료된다.

성숙체중에 관한 모수 $A$ 의 경우 $179.69 \pm$ $4.40 \mathrm{~kg}$ 으로 추정되어 이(2001)가 듀록, 랜드레이
스 및 요크셔 품종 전체에 대해 암수 각각 $171.9 \pm 3.70 \mathrm{~kg}$ 및 $172.3 \pm 3.99 \mathrm{~kg}$ 으로 추정한 결과

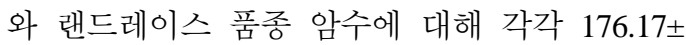
$4.17 \mathrm{~kg}$ 및 $201.97 \pm 6.82 \mathrm{~kg}$ 으로 보고한 조 등(2001) 의 결과와는 비슷하거나 약간 낮게 나타났다. 성숙률에 관한 성장곡선 모수, $k$ 는 $0.3103 \pm$ 0.0043 으로 추정되어 재래돼지와 랜드레이스 품종에 대해 0.3284 3742의 범위로 보고한 조 등(2001)의 결과에 비해 낮은 수치로 만숙성 의 성장특성을 보인 것으로 나타났다.

성장속도가 최대가 되는 시기인 변곡점 $\left(t_{I}\right)$ 은 $5.14 \pm 0.09$ 월령으로 추정되어 재래돼지 암수 각 각 4.63 및 4.86월령 그리고, 랜드레이스 암수 각각 4.31 및 4.56월령으로 보고한 조 등(2001) 의 결과에 비해 늦는 것으로 나타났다. 변 곡점에서의 증체 속도 $\left(\partial W_{t} / \partial t\right)$ 는 $19.185 \pm 0.237$ 으 로 추정되어 조 등(2001)이 재래돼지 암수에 대 해 각각 평균 14.019 및 14.624, 그리고 랜드레 이스 품종 암수 각각 23.501 및 25.612으로 보 고한 결과에 대해 중간 범위로 나타났다.

Table 2에는 개체별 성장곡선 모수 및 성장 특성치에 대한 성별과 분만 그룹의 효과를 표 시하였다. F2 집단의 수컷은 암컷에 비해 성숙 체중 $(A)$ 이 무겁고, 높은 $k$ 값으로 조숙성이며 변곡점 $\left(t_{I}\right)$ 월령이 빠르며 최대 증체 속도 $\left(\partial W_{t} / \partial t\right)$ 가 높게 나타났으나 통계적인 유의성 은 없었다(p>.05). 분만 그룹의 효과는 성숙체중 과 최대 증체속도에 대해 유의적인 효과를 가지는 것으로 나타났는데 이는 분만 시기에 따른 계절 및 사육환경의 영향으로 사료된다(p<.05).

$L E P R$ 표지인자의 다형성에 따른 성장특성의 차이는 Table 3에 표시한 바와 같다. 조사된 9 개의 유전자형에 대해 성숙체중 $(A)$ 의 경우

AA

Table 1. Means with their standard errors and coefficients of variation of growth curve parameters using Gompertz model for the individual weight-age data ${ }^{1)}$

\begin{tabular}{cccccc}
\hline$A$ & $b$ & $k$ & $W_{t I}$ & $t_{1}$ & $\partial W t_{l} / \partial t$ \\
\hline \hline $179.69 \pm 4.40$ & $4.5441 \pm 0.0242$ & $0.3103 \pm 0.0043$ & $69.36 \pm 1.69$ & $5.14 \pm 0.09$ & $19.185 \pm 0.237$ \\
0.387 & 0.085 & 0.218 & 0.387 & 0.264 & 0.196 \\
\hline
\end{tabular}

${ }^{\Gamma} A, b$ and $k$ are fitted parameters for mature weight, growth ratio and maturing rate, respectively; $W t_{I}$ is weight at inflection; $t_{I}$ is age of month at point of inflection; $\partial t_{I} / \partial$ is maximum rate of growth gain $(\mathrm{kg} / \mathrm{month})$, which means the slope of curve at inflection. 
유전자형일 경우 가장 높게 추정되었으며, 성 성장률을 개선시킨다고 보고하였는데, 본 연구

Table 2. Least square means and their standard errors of growth curve parameters using Gompertz model for the individual weight-age data by calving and $\operatorname{sex}^{1)}$

\begin{tabular}{lcccccc}
\hline & & $n$ & $A$ & $k$ & $t_{1}$ & $\partial W t_{l} / \partial t$ \\
\hline \hline \multirow{2}{*}{ Sex } & Male & 131 & $178.24 \pm 6.26$ & $0.3156 \pm 0.0062$ & $5.04 \pm 0.12$ & $19.428 \pm 0.333$ \\
& Female & 122 & $177.29 \pm 6.51$ & $0.3079 \pm 0.0064$ & $5.17 \pm 0.13$ & $18.783 \pm 0.346$ \\
\hline \multirow{2}{*}{ Calving $^{2)}$} & 1st & 147 & $190.73 \pm 5.77^{\mathrm{a}}$ & $0.3092 \pm 0.0057$ & $5.23 \pm 0.11$ & $20.025 \pm 0.307^{\mathrm{a}}$ \\
& 2nd & 106 & $164.80 \pm 7.39^{\mathrm{b}}$ & $0.3143 \pm 0.0073$ & $4.98 \pm 0.15$ & $18.185 \pm 0.393^{\mathrm{b}}$ \\
\hline
\end{tabular}

${ }^{1)} A$ and $k$ are fitted parameters for mature weight and maturing rate, respectively; $t_{I}$ is age of month at point of inflection; $\partial t_{I} / \partial$ is maximum rate of growth gain $(\mathrm{kg} / \mathrm{month})$, which means the slope of curve at inflection.

${ }^{2)} \mathrm{F} 2$ populations were divided into two calving group; first group were born in May lly, 2000, and second group were born in February pril, 2001.

Table 3. Least square means and their standard errors of growth curve parameters using Gompertz model for the individual weight-age data by LEPR genotype ${ }^{1)}$

\begin{tabular}{cccccc}
\hline Genotype & $n$ & $A$ & $k$ & $t_{1}$ & $\partial W t_{l} / \partial t$ \\
\hline \hline$A A$ & 16 & $227.53 \pm 17.15^{\mathrm{a}}$ & $0.2680 \pm 0.0169^{\mathrm{c}}$ & $6.03 \pm 0.34^{\mathrm{a}}$ & $20.963 \pm 0.912^{\mathrm{a}}$ \\
$A B$ & 20 & $177.13 \pm 15.17^{\mathrm{bc}}$ & $0.2990 \pm 0.0150^{\mathrm{bc}}$ & $5.32 \pm 0.30^{\mathrm{ab}}$ & $18.150 \pm 0.807^{\mathrm{bc}}$ \\
$B B$ & 18 & $170.03 \pm 16.37^{\mathrm{bc}}$ & $0.3301 \pm 0.0161^{\mathrm{a}}$ & $4.77 \pm 0.32^{\mathrm{bc}}$ & $19.561 \pm 0.870^{\mathrm{abc}}$ \\
$B C$ & 23 & $159.03 \pm 14.25^{\mathrm{bc}}$ & $0.3210 \pm 0.0140^{\mathrm{a}}$ & $4.78 \pm 0.28^{\mathrm{bc}}$ & $17.839 \pm 0.758^{\mathrm{c}}$ \\
$C C$ & 33 & $170.58 \pm 11.71^{\mathrm{bc}}$ & $0.3070 \pm 0.0115^{\mathrm{bc}}$ & $5.17 \pm 0.23^{\mathrm{b}}$ & $17.995 \pm 0.623^{\mathrm{c}}$ \\
$C E$ & 61 & $186.23 \pm 8.66^{\mathrm{b}}$ & $0.2986 \pm 0.0085^{\mathrm{bc}}$ & $5.35 \pm 0.17^{\mathrm{ab}}$ & $19.069 \pm 0.460^{\mathrm{abc}}$ \\
$D D$ & 25 & $141.75 \pm 13.94^{\mathrm{c}}$ & $0.3510 \pm 0.0137^{\mathrm{a}}$ & $4.30 \pm 0.27^{\mathrm{c}}$ & $18.211 \pm 0.741^{\mathrm{bc}}$ \\
$D E$ & 24 & $183.99 \pm 13.70^{\mathrm{b}}$ & $0.3181 \pm 0.0135^{\mathrm{a}}$ & $5.08 \pm 0.27^{\mathrm{b}}$ & $20.258 \pm 0.728^{\mathrm{a}}$ \\
$E E$ & 33 & $183.62 \pm 11.91^{\mathrm{b}}$ & $0.3128 \pm 0.0117^{\mathrm{b}}$ & $5.14 \pm 0.23^{\mathrm{b}}$ & $19.900 \pm 0.633^{\mathrm{ab}}$ \\
\hline
\end{tabular}

${ }^{1)} A$ and $k$ are fitted parameters for mature weight and maturing rate, respectively; $t_{I}$ is age of month at point of inflection; $\partial t_{I} / \partial$ is maximum rate of growth gain $(\mathrm{kg} / \mathrm{month})$, which means the slope of curve at inflection.

숙률 $(k)$ 은 가장 낮게 나타났는데(I $<.05)$, 이는 $\mathrm{AA}$ 유전자형을 가지는 개체는 만숙성의 성장 특성을 가지며, 전 생애 가운데 성장률의 증가 속도가 지속적으로 증가하는 기간의 한계인 변 $\mathrm{A}$ 곡점 $\left(t_{I}\right)$ 이 비교적 늦으며 따라서 성숙체중의 최대치는 비교적 무거운 경향을 보일 것으로 사료된다. 반면 유전자형이 $\mathrm{DD}$ 인 경우, 성숙체 중 $(A)$ 과 변곡점 $\left(t_{I}\right)$ 추정치가 비교적 가장 낮 았으며, 성숙률 $(k)$ 이 높게 추정되어 상대적으 로

초기 성장이 빠른 조숙성의 성장 특성으로 가 지지만, 성장률의 증가추세가 일찍 감소하며, 따라서 성숙체중의 최대치는 낮을 것을 추정되 었다.

Emnett 등(2000)은 돼지의 경제형질에 대한 $L E P R$ 관련 $\mathrm{PCR}-\mathrm{RFLP}(\mathrm{MboI})$ 의 효과에 대한 연 구에서 대립유전자 B형이 $\mathrm{A}$ 형에 비해 등지방 두께를 감소시키고 증체율을 향상시킴으로써
의 결과에서는 $\mathrm{BB}$ 유전자형이 $\mathrm{AA}$ 유전자형에 비해 성숙률 $(k)$ 은 높게, 성숙체중 $(A)$ 과 변곡점 $\left(t_{I}\right)$ 은 낮게 추정되었지만(p <.05), 최대 성장속 도 $\left(\partial W t_{l} / \partial t\right)$ 차이에는 유의성이 없는 것으로 나타났다(p>.05). 이는 $\mathrm{A}$ 형에 비해 단기간에 비슷한 최대성장률의 변곡점에 도달한 $\mathrm{B}$ 형이 초기 성장이 빠른 조숙성이라는 측면은 부합되 는 결과이지만, 성장률의 증가추세가 성장 후 반기까지 지속되지 못하여 성숙체중의 최대치 는 낮아질 것으로 추정되어 초기성장에 대한 해석만으로 전 생애에 걸친 성장특성에 대한 해석은 무리가 있음을 알 수 있다. 따라서 조 사된 LEPR 관련 초위성체 표지인자 유전자형 의 다형성에 따른 성장 특성의 해석 및 예측이 가능하며 그 범위는 생애 전반에 걸쳐 적용해 야 할 것으로 사료된다.

$$
\text { IV 요 약 }
$$


본 연구는 재래돼지와 랜드레이스 품종을 기 초축으로 조성한 F2 집단의 일령별 체중 자료 를 이용하여 비선형 회귀에 의해 추정한 개체 별 성장곡선 모수 및 성장 특성치에 대한 $L E P R$ 관련 초위성체 표지인자의 다형성에 따 른 효과를 추정함으로써 Leptine 수준에 따른 성장 형질의 특성을 규명하고자 실시하였다.

조사된 $\mathrm{F} 2$ 집단에 대해 개체별 성숙체중 $(A)$ 과 성숙률 $(k)$ 의 평균은 각각 $179.69 \pm 4.40 \mathrm{~kg}$ 및 $0.3103 \pm 0.0043$ 으로 추정되었으며, 성장 특성에 대한 성의 효과는 통계적 유의성이 없었으며 (p).05), 성숙체중 $(A)$ 및 최대 증체 속도 $\left(\partial W_{t} / \partial t\right)$ 는 분만 그룹에 따른 유의적인 차이를 보였다(1<.05). 조사된 모든 성장특성에 대해 $L E P R$ 표지인자의 다형성 효과는 유의적으로 나타났으며 $(\mathrm{p}<.05), \mathrm{AA}$ 유전자형을 가지는 개 체는 만숙성이며, 반면 유전자형이 $\mathrm{DD}$ 인 경우, 조사된 유전자형들 가운데 초기 성장이 빠른 조숙성의 성장 특성으로 가지지만, 성장률의 증 가추세가 일찍 감소하며, 성숙체중의 최대치는 낮을 것을 추정되었다. 따라서 조사된 $L E P R$ 관 련 표지인자 유전자형의 다형성에 따른 성장 특 성의 해석 및 예측이 가능하며, 그 범위는 생애 전반에 걸쳐 적용해야 할 것으로 사료된다.

\section{$\mathrm{V}$ 인 용 문 헌}

1. Baratta, M., Saleri, R., Mainardi, G. L., Valle, D., Giustina, A. and Tamanini, C. 2002. Leptin regulates GH gene expression and secretion and nitric oxide production in pig pituitary cells. Endocrinology 143:551-557.

2. Barb, C. R., Yan, X., Azain M. J., Kraeling, R. R., Rampacek, G. B. and Ramsay, T. G. 1998. Recombinant porcine leptin reduces feed intake and stimulates growth hormone secretion in swine. Domest. Anim. Endocrinol 15:77-86.

3. Brown, J. E., Fitzhugh, Jr., H. A. and Cartwright, T. C. 1976. A comparison of nonlinear models for describing weight-age relationship in cattle. J. Anim. Sci. 42:810.

4. Chen, G., Koyama, K., Yuan, X. Lee, Y., Zhou, Y. T., O'Doherty, R., Newgard, C. B. and Unger,
R. H. 1996. Disappearance of body fat in normal rats induced by adenovirus-mediated leptin gene therapy. Proceedings of the National Academy of Science, USA. 93:14795-14799.

5. Clement, K., Vaisse, C., Lahlou, N., Cabrol, S., Pelloux, V., Cassuto, D., Gourmelen, M., Dina, C., Chambaz, J, Lacorte, J. M., Basdevant, A., Bougnes, P., Lebouc, Y., Froguel, P. and Guy-Grand, B. 1998. A mutation in the human leptin receptor gene causes obesity and pituitary dysfunction. Nature 392:398-401.

6. Emnett, R., Moeller, S., Irvin, K., Rothschild, M., Plastow, G. and Goodwin, R. 2000. An Investigation into the genetic controls of pork quality. NSIF Proceedings.

7. Lin, J., Barb, C. R., Kraeling, R. R. and Rampaek, G. B. 2003. Growth hormone releasing factor decreases long form leptin receptor expression in porcine anterior pituitary cells. Domestic Animal Endocrinology 24:95-101.

8. Ramsay, G., Yan, X. and Morrison, C. 1998. The Obesity Gene in Swine: Sequence and Expression of Porcine Leptin. J. Anim. Sci. 76:484-490.

9. Reichart, U., Renner-Muller, I., Hoflich, A., Oliver J., Muller, Wolfgang, M. F., Wolf, E., Muller, M., Brem, G. and Aigner, B. 2000. Contrasting Obesity Phenotypes Uncovered by Partial Leptin Receptor Gene Deletion in Transgenic Mice. Biochemical and Biophysical Research Communications. 269:502-507.

10. Roh, S. G., Nie, G. Y., Loneragan, K., Gertler, A. and Chen, C. 2001. Direct modification of somatotrope function by long-term leptin treatment of primary cultured ovine pituitary cells. Endocrinology 142: 5167-5171.

11. SAS. 2000. SAS/STAT User's guide. SAS institute Inc., Cary, NC., USA.

12. Winsor, C. R. 1932. The Gompertz curve as a growth curve. Proc. Natl. Acad. Sci. 18:1.

13. Zhang, Y., Proenca, R., Maffei, M., Barone, M., Leopold, L. and Friedman, J. M. 1994. Positional cloning of the mouse obese gene and its human homologue. Nature 372:425-432.

14. 이일주. 2001. 돼지의 검정 종료 체중과 측정 모 드에 따른 경제 형질의 유전 모수 및 성장 곡선 모수의 추정. 서울대학교 박사학위논문.

15. 조용민, 윤호백, 이영창, 서강석, 김시동, 박영일. 2001. 개체별 성장곡선 모수를 이용한 재래돼지 와 랜드레이스종의 성장 특성에 관한 연구. 한국 동물자원과학회지 43(6):817-822.

(접수일자 : 2003. 6. 2. / 채택일자 : 2003. 11. 5.) 